\title{
International Impact of Productivity Shocks with E ndogenous Labor Supply: The Two Large Economy Case
}

\author{
Ali Kocyigit \\ Florida International University
}

\begin{abstract}
The study constructs a deterministic, overlapping-generations, two-economy model. The analysis is conducted in the context of an infinitely-lived economy where indi viduals have finite ( two-periods) lifetimes. The model shows that a positive producti vity shock produces positive correlation between savings and investment despite the fact that there is perfect international capital mobility. Further, the simulation results show that the endogeneity of the labor supply gives rise to cyclical adjustment of the economy towards its steady state. (JE L Classification: F 4)
\end{abstract}

\section{Introduction}

This study constructs a deterministic, overlapping-generations (OLG), two-economy model to explore responses of the two economies to produc-

* Correspondence Address: D epartment of E conomics, University Park, M iami, F lori- 
tivity shocks under conditions of perfect international capital mobility. The focus of the analysis is on the relationship between savings and investment in large open economies ( $L O E$ ). Employing simulation, the model is used to generate time-series for the LOE's savings and investment. The savingsinvestment correlations obtained from the simulated time series are then compared with the actual data for specific economies.

The analysis is conducted in the context of an infinitely-lived economy as in Obstfeld [1986], Tesar [1988, model I], Finn [1990] and M endoza [1991]. Finn [1990] observes that this assumption provides interesting savings and investment dynamics. Since only one saving and one investment decision is being made, she points out that restricting the lifetime of the economy to, for instance, two periods precludes savings and investment dynamics in the strict sense of the word. In the infinitely-lived economy, individuals have finite lifetimes of two-periods, as in M urphy [1986], Tesar [1988, models I and II], Finn [1990] but in contrast to Obstfeld and M endoza [1991]. As indicated by Finn [1990], this assumption assures nice stability properties for the model without putting arbitrary restrictions on the rate of time preference. Also, in this model, in contrast to Obstfeld [1986], Murphy [1986], Tesar (1988, models I and II) but as in Finn [1990], productivity shocks will have effects on both domestic and foreign technologies.

The issue of the positive correlation between savings and investment under conditions of perfect international capital mobility has been the subject of a substantial empirical literature in response to the work of F eldstein and Horioka [1980]. One interpretation of the evidence that there exist significantly positive cross-sectional and time-series correlations between savings and investment is that this finding implies international capital immobility. The analysis undertaken here shows that this interpretation of the evidence is not necessarily the correct one. The paper suggests that by having 
savings and investment are correlated because of the connection between consumption growth and capital stock accumulation.

When labor supply is endogenous, an increase in investment rises capital stock. This in turn leads to a higher marginal productivity of labor and as a result higher wage level. The rise in the wage rate increases labor supply and this leads to a fur ther rise in income. This in turn increases savings.

In the presence of the non-traded goods, however, production decisions depend upon consumption choices for the non-traded goods. Thus, when savings increase (decrease) consumption of non-traded goods falls (rises). As a result, production of non-traded sector in the home economy also falls. This shrinkage in non-traded sector causes factors of production to move out of this sector. If the non-traded sector is relatively labor intensive, the marginal productivity of capital rises. Therefore the desired capital stock will rise and that will cause a positive correlation between savings and investment.

In what follows, our discussion focuses on two large open economies represented by a Samuelson-Diamond type overlapping generations model. The study also endogenizes the labor supply decisions of households. This gives rise to the cyclical adjustment of the world economy towards its steady-state. The model is parameterized, calibrated, and simulated to explore the causes behind the degree of correlation between savings and investment.

The rest of the paper is organized as follows. Section II describes the autarkic equilibrium of the two economies. In section III, we analyze the open economy equilibrium. Section IV presents the results of simulations for a benchmark model, and compares these with the actual data for the three largest economies in the world. Section $V$ concludes the paper. 
sumption and investment. The supply of capital is determined endogeneously by the savings behavior of individuals.

\section{B. Momentary Equilibrium}

Labor supply, $L$, by individuals is endogenous. The rate of growth of population, $h$, in each economy is for simplicity assumed to be zero. $N_{t+1}=N_{t}=N$, where $\mathrm{N}$ represents the size of the generation in a given time period in the economy. Individuals live for two periods. Thus, the economy, at any point in time, is comprised of two generations, the young and the old. M embers of each generation are identical. Every individual works only in the first period of his/ her life in which he/ she is endowed with one unit of labor, and retires in the second period. Individual utility is defined over commodity consumptions, $c_{t}^{1}, c_{t}^{2}$, in periods $t$ and $t+1$ and leisure in period $t$.

The representative individual born at time $t$ maximizes lifetime utility over consumption, $c_{t}^{1}, c_{t}^{2}$, and leisure paths, that is, he/ she maximizes

$$
V\left(c_{t}^{1}, c_{t}^{2}, L_{t}\right)=U\left(c_{t}^{1}, L_{t}\right)+(1+)^{-1} U\left(c_{t}^{2}\right)
$$

Subject to

$$
\left(w_{t} L_{t}-c_{t}^{1}\right)\left(1+r_{t+1}\right)=c_{t}^{2}, \quad c_{t}^{1}, c_{t}^{2} \geq 0,0 \leq L_{t} \leq 1
$$

where $\rho, C_{t}^{1}, c_{t}^{2}, L_{t}, w_{t}, r_{t+1}$ denote the rate of time preference, first period consumption, second period consumption, labor supply, the wage rate and the rate of interest. The second period consumption is financed from savings: $c_{t}^{2}=r_{t+1} \cdot s_{t}$ where $s_{t}$ represents the savings in the first period. The budget constraint of an individual is given by $c_{t}^{1}+S_{t} \leq L_{t} W_{t}$. The instantaneous utility functions $\mathrm{U}\left(\mathrm{c}_{\mathrm{t}}^{1}, \mathrm{~L}_{\mathrm{t}}\right)$ and $\mathrm{U}\left(\mathrm{c}_{\mathrm{t}}^{2}\right)$ are assumed to have following properties:

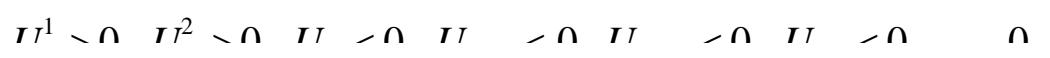




$$
\begin{aligned}
& U_{c^{1}}\left(c_{t}^{1}, L_{t}\right)-\left(1+r_{t+1}\right)=0 \\
& (1+)^{-1} U_{c^{2}}\left(c_{t}^{2}\right)-=0 \\
& U_{L}\left(c_{t}^{1}, L_{t}\right)+\left(1+r_{t+1}\right) w_{t}=0 \\
& \left(w_{t} L_{t}-c_{t}^{1}\right)\left(1+r_{t+1}\right)-c_{t}^{2}=0
\end{aligned}
$$

At the beginning of any time period, the young generation supplies labor, which combined with the capital stock owned by the old generation produces the flow of output. Since the old generation in period $t+1$ is retired, its labor earnings in period $t+1$ equal zero. Since labor and capital markets are competitive, profit maximization by firms implies that the marginal product of labor equals the real wage rate.

$$
w_{t}=f\left(k_{t}\right)-k_{t} f^{\prime}\left(k_{t}\right)
$$

where $f\left(k_{t}\right)$ is output per worker, and $k_{t} \equiv K_{t} / L_{t}$. The production function satisfies the Inada conditions. Similarly, the optimum choice of capital equates the rate of interest to the marginal product of capital:

$$
r_{t+1}=f^{\prime}\left(k_{t+1}\right)
$$

The savings of each member of generation $t$ is related to the capital stock of the next period by:

$$
S\left(w_{t}, r_{t+1}\right)=w_{t} L_{t}-c_{t}^{1}=K_{t+1}
$$

or

$$
S\left(w_{t}, r_{t+1}\right)=w_{t} L_{t}-C_{t}^{1}=k_{t+1} L_{t+1}
$$

Solving equations (3)-(6) for $c_{t}^{1}, c_{t}^{2}$, and $L_{t}$ as functions of $w_{t}, r_{t+1}$, and $\rho$, we 


\section{The Two-Economy Equilibrium}

The two large open economies are connected by an international commodity market and an international capital market in the model. From now on variables associated with the foreign country will be indicated by a bolditalic letter for the relevant variables. The foreign economy is assumed to have a lower rate of time preference than the home economy. In addition, output can be moved costlessly between the economies, and domestic and foreign capital are perfect substitutes in portfolios of households. Thus, interest rates are equalized in the world economy:

$$
r_{\mathrm{t}}=\mathrm{r}_{\mathrm{t}} \quad \forall_{\mathrm{t}}
$$

There is only one perfect world market for capital and for the current production of the homogenous commodity. Since there is international capital mobility, it is important to distinguish between the value of claims on real, domestic or foreign capital, $A_{t}$, owned by domestic households, and the capital stock, $\mathrm{K}_{\mathrm{t}}$, used in production in the home country. This distinction gives us the difference between gross domestic product and national product in national income accounting. Location and ownership of physical capital will not coincide anymore. Because of the perfect substitution between domestic and foreign real capital, free trade in the capital market, interest rate equalization, and identical, linear homogenous production functions, the capital-labor ratios and wage rates will be equal in both economies:

$$
\begin{aligned}
& k_{t}=k_{t} \\
& w_{t}=w_{t}
\end{aligned}
$$

The behavior of the integrated world economy is given by the optimizing hohavinr of domoctir and foroion houcoholde fartor markat oriılihrium 
countries are integrated, the world capital market equation is given by:

$$
W_{t} L_{t}+W_{t} L_{t}-C_{t}^{1}-C_{t}^{1}=k_{t+1}\left[L_{t+1}+L_{t+1}\right]
$$

Given the predetermined value of $k_{t}=k_{t}$, the model determines the momentary equilibrium values of $c_{t}^{1}, c_{t}^{2}, L_{t}, c_{t}^{1}, c_{t}^{2}, L_{t}, w_{t}, r_{t+1}$ and $k_{t+1}$.

Substituting equation (10) (with its counter-part equation for foreign economy) into the world capital market equation, (15), and using equations (7) and (8) (with their counter-parts for foreign country) will give us a second-order difference equation in $k_{t}$ which describes the evolution of the model from arbitrary initial conditions: ${ }^{1}$

$$
\begin{aligned}
& f\left(k_{t}\right)-k_{t} f^{\prime}\left(k_{t}\right)\left[f\left(k_{t}\right)-k_{t} f^{\prime}\left(k_{t}\right), f^{\prime}\left(k_{t+1}\right) ; \rho+f^{\prime}\left(k_{t}\right)-k_{t} f^{\prime}\left(k_{t}\right), f^{\prime}\left(k_{t+1}\right) ; \rho\right] \\
& -\left\{c^{1}\left[f\left(k_{t}\right)-k_{t} f^{\prime}\left(k_{t}\right), f^{\prime}\left(k_{t+1}\right) ; \rho\right]+c^{1}\left[f\left(k_{t}\right)-k_{t} f^{\prime}\left(k_{t}\right), f^{\prime}\left(k_{t+1}\right) ; \rho\right]\right\} \\
& =k_{t+1}\left[f\left(k_{t+1}\right)-k_{t+1} f^{\prime}\left(k_{t+1}\right), f^{\prime}\left(k_{t+2}\right) ; \rho+f\left(k_{t+1}\right)-k_{t+1} f^{\prime}\left(k_{t+1}\right), f^{\prime}\left(k_{t+2}\right) ; \rho\right]
\end{aligned}
$$

\section{A. The Balance of Payments Account}

Analyzing the balance of payments account of one of the two economies will be sufficient to obtain results for a two-economy world, because

$$
B_{t+1}=-B_{t+1}
$$

and

$$
C A_{t+1}=-C A_{t+1}
$$

where $B_{t+1}$ represents the trade balance surplus of the home country in period $t+1$, and $C A_{t+1}$ represents the current account surplus of the home country in period $t+1$. Under the condition of no official balance settlements, the cur rent account surplus (deficit) of a countrv is identicallv equal 
or

$$
b_{t+1}=f\left(k_{t+1}\right)-c_{t+1}^{1}-c_{t}^{2}-\left(k_{t+2}-k_{t+1}\right)
$$

The current account surplus is the excess of national product over domestic absorption. National product equals domestic product plus net foreign investment income. If we define $A_{t+1}$ as the wealth of the home economy at the beginning of period $t+1$, then the net claims on the rest of the world will be $A_{t+1}-K_{t+1}$ and the net foreign investment income will be $r_{t+1}\left(A_{t+1}-K_{t+1}\right)$. The economy's wealth at the beginning of period consists of the accumulated savings of the members of generation $t$ as:

$$
A_{t+1}=\left(w_{t} L_{t}-c_{t}^{1}\right) N
$$

or

$$
a_{t+1}=w_{t} L_{t}-c_{t}^{1}
$$

As indicated by Buiter [1981], national wealth differs from the value of domestic capital stock because of the opportunity for international borrowing and lending, and different rates of time preference. There is a presumption that an economy consisting of people with high (low) rates of time preference will tend to be a net foreign borrower (lender). This supposition might be examined as follows:

The current account deficit of the home economy is given by

$$
C A_{t+1}=N f\left(K_{t+1}\right)+r_{t+1}\left(A_{t+1}-K_{t+1}\right)-c_{t+1}^{1} N-c_{t}^{2} N-\left(K_{t+2}-K_{t+1}\right),
$$

or

$$
c a_{t+1}=f\left(k_{t+1}\right)+r_{t+1}\left(a_{t+1}-k_{t+1}\right)-c_{t+1}^{1}-c_{t}^{2}-\left(k_{t+2}-k_{t+1}\right)
$$

With CRS in production and marginal productivity factor pricing, $f\left(\mathrm{k}_{\mathrm{t}+1}\right)=$ $\mathrm{w}_{\mathrm{t}+1}+\mathrm{r}_{\mathrm{t}+1} \mathrm{k}_{\mathrm{t}+1}$, equation (21') can be written as:

$$
c a_{+, 1}=w_{+, 1}+r_{+, 1} a_{+, 1}-c_{+11}^{1}-c_{+}^{2}-\left(k_{+, 2}-k_{+, 1}\right) \text {. }
$$




$$
c a_{t+1}=a_{t+2}-a_{t+1}-\left(k_{t+2}-k_{t+1}\right) .
$$

\section{B. Steady-State Equilibrium}

We define the steady-state equilibrium of the two-country model by the following equations for the home economy and as well as for their counterparts where necessary:

$$
\left(w L-c^{1}\right)(1+r)=c^{2}
$$

The factor and capital market equilibrium conditions are given by the equations:

$$
\begin{aligned}
& w=f(k)-k f^{\prime}(k) \\
& r=f^{\prime}(k)
\end{aligned}
$$

Stationary world capital market equilibrium conditions, as well as homeeconomy net worth are shown by the equations:

$$
\begin{aligned}
& w[L+L]-c^{1}-c^{1}=k[L+L] \\
& a=w L-c^{1}
\end{aligned}
$$

The steady-state balance of payment equations are given as:

$$
\begin{aligned}
& b=f(k)-c^{1}-c^{2} \\
& c a=f(k)+r(a-k)-c^{1}-c^{2}, \\
& c a=0
\end{aligned}
$$

C. Parameter Values and Calibration 
The model is parameterized so as to make it roughly consistent with some of the empirical regularities that reflect the structure of a large open economy with a high degree of integration with world financial markets. In that sense, US, Japan, and Germany are considered to fit this definition. In order to solve the model, values are chosen for the parameters $\theta, \alpha, \sigma, \rho$ and $\rho$, that represent the productivity coefficient, the share of capital, the coefficient of relative risk aversion, and pure rate of time preferences for home and foreign economies. The data considered for US, Japan, and Germany comprises of annual observations for the period 1970-92, detrended with a quadratic time trend in order to assure stationarity. On the other hand, the simulated data consists of 15 periods. The statistical moments for actual and simulated data are reported in Table I (see Appendix B).

The values of the parameters are selected using actual data and the restrictions imposed by the structure of the model as well as from the relevant empirical literature. The productivity shock is set to equal to ten percent. The share of capital ( is set to equal to the average capital share in production in the three largest economies excluding human capital. The capital's share in production has been calculated by Kydland and Presscott [1982] using US time series data, and was found to be 0.36 . Several other studies like Devereux and Love [1994] and Hansen [1985] also adapt the same value by following Kydland and Presscott [1982], Presscott [1986], and King and Rebelo [1990]. On the other hand, M endoza [1991] sets the value of $\alpha$ to 0.32 . In the absence of human capital, however, we adapt the value of 0.25 .

The relative risk aversion parameter, $\sigma$, is assumed to be 4 in the benchmark parameterization of this study. There is no consensus, however, about the value of the risk aversion parameter. Kydland and Presscott [1982], for instance, estimated that the risk aversion parameter was near zero. M en- 
determined by the literature, and it is chosen to be in the range of zero to two hundred percent. This study sets the rate of time preferences 0.9600 and 0.9463 for the domestic and the foreign economies respectively, which imply a steady-state annual rate of interest of approximately eight percent.

In summar $y$, these parameters are set as follows: $\theta=1$, and (before and after the productivity shock), $\alpha=0.25, \sigma=4, \rho=0.9600, \rho=0.9463$.

\section{The Benchmark Model}

\section{A. The Effects of Positive Productivity Shock}

This section of the study presents the basic framework of real business cycles in a large open economy. In this framework, the technologies of both the domestic and the foreign economy are affected by a positive productivity shock of ten percent.

The model developed above shows cyclical adjustments due to endogenous labor supply. The fact that labor supply is endogenous implies that the marginal productivity of capital and thus investment are altered by changes in the labor supply. Also, Karayalcin [1995] argues that the endogenous labor supply establishes an additional link between investment decisions of the firms and consumption, savings, and labor supply decisions of the households that is absent in the exogenous labor supply models.

Figure I (see Appendix A) depicts the transient paths of the capital stock $K$, labor supply $L$, aggregate consumption $A C$, output $Y$, savings $S$, investment $I$, the wage rate $w$, the interest rate $r$, the cur rent account surplus $C A$, and the balance of trade surplus $B$. Simulation shows that when a positive productivity shock hits the economy, this raises the capital stock in the longrun. The rise in the capital stock causes a positive substitution effect and a 
sating fall in net external assets of the home country, and thus, across steady-states foreign asset holdings decline. Hence, the balance of trade surplus of the home country decreases across steady-states. Since the rate of population growth is zero, at the new steady state the economy's current account surplus will be zero.

On impact, an increase in productivity leads to a positive wealth effect in the economy. This increases consumption. However, the rise in the wage rate on impact dominates the initial positive wealth effect leading to an increase in labor supply and thus employment on impact. Since the capital stock is predetermined on impact, the increase in labor supply causes a decline in capital-labor ratio. This coupled with the rise in productivity leads to a rise in the world interest rate on impact. Also note that since home economy's rate of time preference is higher than the foreign economy's time preference, the consumption level for the home economy will be higher than that of foreign economy after the positive productivity shock. F urthermore, on impact, the productivity shock raises output.

On impact, the impatient (high rate of time preference) home economy engages in an intertemporal substitution of its consumption, raising its current consumption which is financed by borrowing. Together with the decline in savings and the increase in investment, this leads to a current account deficit in the home economy. On the other hand, the patient (low rate of time preference) foreign economy experiences a current account surplus on impact. That is, the economy with the higher rate of time preference (home economy) has a current account deficit on impact since it has a higher value of consumption right after the positive productivity shock.

To see how the cyclical adjustment of the economy continues, it is now sufficient to discuss briefly the change in the capital stock. The simulation 
labor income to the degree that though it is accompanied by a decrease in consumption savings and investment decline.

Simulation also shows that the home economy runs a current account surplus in the first stage of the adjustment indicating that the decline in consumption and investment outweighs the effects of the dissavings. On the other hand, the foreign economy runs a current account deficit. The simulation results suggest that after eleven periods the cyclical adjustment of the variables brings the economy arbitrarily close to its steady-state.

\section{B. The Empirical Results}

In this section I compare the statistical moments produced by the benchmark model with the moments obtained from three large open economies, namely, US, J apan, and Germany. Table I (see Appendix B) provides statistics describing the cyclical behavior of the US, Japanese and German economies, and the benchmark model developed above. For each economy, and the benchmark model, three columns of statistics are reported. Column (1) provides a measure of volatility (the standard deviation of the variable); column (2) provides a measure of first-order serial autocorrelation; and column (3) provides a measure of comovement (the contemporaneous correlation with GDP).

The parameterized benchmark model and actual data for US, Japan, and Germany replicate the following patterns. Looking first at the benchmark model, we observe that despite its anomalies, it does well in mimicking the actual data in terms of the savings-investment correlation. The high correlation between savings and investment in the benchmark model replicates this feature of the German, US, and particularly J apanese data remarkably well $(0.998$ vs. $0.735,0.802$, and 0.922 respectively). However, the high cor- 
ment rates may cause these variables to be highly correlated.

Second, we typically observe that consumption and savings are less volatile than output and investment is more volatile than output in the benchmark model. These results are in accord with the actual data with the exception of savings. However, the benchmark model underestimates the extent of volatility for savings compared to actual data for all three economies. Compared to J apanese data, the balance of trade surplus and the current account surplus display considerably high volatility in the benchmark model. However, they fairly mimic the US and the German data ( $0.179,0.136$ vs. 0.129 , 0.151 , and $0.184,0.180$ respectively) in this respect. Furthermore, the volatility of the GDP and the aggregate consumption in the benchmark model are relatively closer to actual data than other variables.

M oreover, for the persistence of the movements in the different variables, as characterized by their first-order autocorrelations, presented in column (2), in contrast to actual data, the benchmark model exhibits negative firstorder autocor relations for savings, investment, the balance of trade surplus, and the current account surplus. Yet the benchmark model performs fairly well for aggregate consumption and particularly for GDP in mimicking the actual data. Investment, on the other hand, shows lower persistency in the benchmark model compared to actual data (-0.364 vs. $0.567,0.712$, and 0.742 for US, Japan, and Germany respectively).

The benchmark model's display of the contemporaneous correlation of the variables with GDP, presented in column (3), shows mixed results. The contemporaneous correlation of aggregate consumption behavior with GDP in the benchmark model mimics the actual data ( 0.799 vs. $0.919,0.971$, and 0.897 for US, Japan, and Germany respectively). Also the contemporaneous correlation of all the variables with GDP in the benchmark model display same signs as the actual data with the exception of savings. 
mixed success in replicating key features of international data such as the comovement between savings and investment and the trade balance and output.

The paper has illustrated that positive productivity shocks to domestic and foreign technologies play a significant role in explaining the observed high savings-investment cor relations and that such high savings-investment correlations do not necessarily stem from the lack of international capital mobility. The model was parameterized and simulated under the following assumptions: (1) time preferences are exogenous; (2) there is no adjustment cost in investment; and (3) the labor supply is endogenous. As reported, the simulated model is consistent with the some of the empirical regularities typical of large open economies. There are some main conclusions to be drawn from the analysis. First, the simulation results show that a positive productivity shock produces positive correlation between savings and investment in a deterministic dynamic equilibrium model despite the fact that there is perfect international capital mobility. This result is consistent with the previous studies like Obstfeld [1986], Finn [1990] and M endoza [1991]. Second, the large economy case shows different results from those occurring in other studies. For example, M endoza [1991] suggests that a small open economy in which capital can be freely accumulated exaggerates the variability of investment and underestimates its correlation with savings. $\mathrm{He}$ also finds that access to foreign markets permits individuals to separate savings and investment by allowing them to finance a gap between the two with external recourses. This study, however, clearly shows that for a large open economy, correlation between savings and investment is quite high and the separation of savings and investment does not play a key role in the performance of the benchmark model. Finally, the economy adjusts cyclically towards its steady-state because of the endogeneity of the labor supply. 


\section{References}

Andolfatto, David [1996], "Business Cycles and Labor-M arket Search," The American Economic Review, M arch 86, N o. 1; pp. 112-32.

Backus, David K., Gregory, Allan W. and Zin, Stanley E. [1989], "Risk Premiums in the Term Structure: Evidence from Artificial Economies," Journal of M onetary E conomics, November 24; pp. 371-400.

Backus, David K. and Kehoe, Patrick J. [1989], "International Evidence on The Historical Properties of Business Cycles," Working Paper No. 420R, Federal Reserve Bank of M inneapolis, Research Department.

Backus, David K. and Kydland, Finn E. [1990], "International Borrowing and World Business Cycles," Working Paper No. 426R, Federal Reserve Bank of M inneapolis, Research Department.

Baxter, M arianne [1995], "International Trade and Business Cycles," NBER Working Paper No. 5025, February.

Baxter, M arianne and M ario J. Crucini [1993], "Explaining Saving-Investment Correlations," The American Economic Review 83, No. 3, June; pp. 416-436.

Buiter, H. Willem [1981], "Time Preference and International Lending and Borrowing in an Overlapping-Generations M odel," Journal of Political E conomy 89, N o. 41; pp. 769-97.

Christiano, Lawrence J. and Eichembaum, Martin [1990], "Current Real Business Cycle Theories and Aggregate Labor Fluctuations," Discus sion Paper No. 24, Federal reserve Bank of M inneapolis, Institute for Empirical $\mathrm{M}$ acroeconomics.

Diamond, A. Peter [ 1965], "National Debt in a N eoclassical Growth M odel," The American Economic Review 55; pp. 1126-1150.

Devereux, B. M ichael, and Shouyong Shi [1991], “Capital Accumulation and 
Feldstein, M artin [1983], "Domestic Saving and International Capital M ovements in the Long-Run and the Short-Run," European Economic Review (Amsterdam) 21 (M arch-April); pp. 129-51.

Feldstein, M artin and Charles Horioka [1980], "Domestic Saving and International Capital Flows," E conomic Journal (London) 90, June; pp. 12951.

Feldstein, Martin and Phillipe Bacchetta [1989], "National Saving and International Investment," NBER Working Paper (Cambridge, MA), No. 3164, N ovember.

Finn, Mary G. [1990], "On Saving and Investment Dynamics in a Small Open Economy," Journal of I nternational E conomics 29, August; pp. 121.

Galor, Oded [1986], "Time Preference and International Labor M igration," Journal of Economic Theory 38; pp. 1-20.

Galor, Oded and Harl E. Ryder [1989], "Existence, Uniqueness, and Stability of Equilibrium in an Overlapping-Generations $\mathrm{M}$ odel with Productive Capital," Journal of Economic Theory 49; pp. 360-75.

Greenwood, Jeremy [1983], "Expectations, The Exchange Rate, and The Current Account," Journal of M onetary Economics 12, November; pp. 543-569.

Greenwood, Jeremy, Hercowitz, Zvi and Huffman, Gregory W. [1988], "Investment, Capacity Utilization, and The Real Business Cycle," American Economic Review 78, June; pp. 402-417.

Greenwood, Jeremy and Zvi Hercowitz [1991], "The Allocation of Capital and Time over the Business Cycle," Journal of Political Economy 99, No. 6; pp. 1188-1214.

Hansen, Gary D. [1985], "Indivisible Labor and The Business Cycle," Jour nal of M onetary E conomics 16, N ovember; pp. 309-327. 
Labor Supply," Journal of Population E conomics 5; pp. 113-34.

Kydland, Finn E. and Edward C. Prescott [1982], "Time to Build and Aggregate Fluctuations," E conometrica 50, N ovember; pp. 1345-1370.

King, Robert G., Plosser, Charles I. and Rebelo, Sergio T. [1988], "Production, Growth, and Business Cycles. I. The N eoclassical M odel," Jour nal of M onetary E conomics 21, M arch; pp. 195-232.

Long, J ohn B. and Plosser, Charles I. [1983], "Real Business Cycles," Jour nal of Political Economy 91, February; pp. 39-59.

Lucas, Robert E., Jr. and Prescott, Edward C. [1971], "Investment Under Uncertainty" 81, Econometrica, September; pp. 659-681.

M endoza, G. Enrique [1991], "Real Business Cycles in a Small O pen Economy," The American E conomic Review 81, September; pp. 797-818.

M urphy, Robert [1984], "Capital M obility and The Relationship Between Saving and Investment Rates in OECD Countries," Journal of Interna tional M oney and Finance 3, December; pp. 327-42.

M urphy, Robert [1986], "Productivity Shocks, N on Traded Goods and Optimal Capital Accumulation," European Economic Review 30; pp. 10811095.

Obstfeld, M aurice [1981], "M acroeconomic Policy, Exchange Rate Dynamics, and Optimal Asset Accumulation," Journal of Political Economy, December 8; pp. 1142-1161.

Obstfeld, M aurice [1986], "Capital M obility in The World Economy: Theories and M easurement," Carnegie-Rochester Conference Series on Public Policy 24, Spring; pp. 55-103.

Sen Partha, Stephen J. Turnovsky [1989], "Tariffs, Capital Accumulation, and The Current Account In A Small Open Economy," Intemational Economic Review 30, November, N o. 4; pp. 811-831.

Stockman, Allan C., Linda L. Tesar [1995], "Tastes and Technology in a 

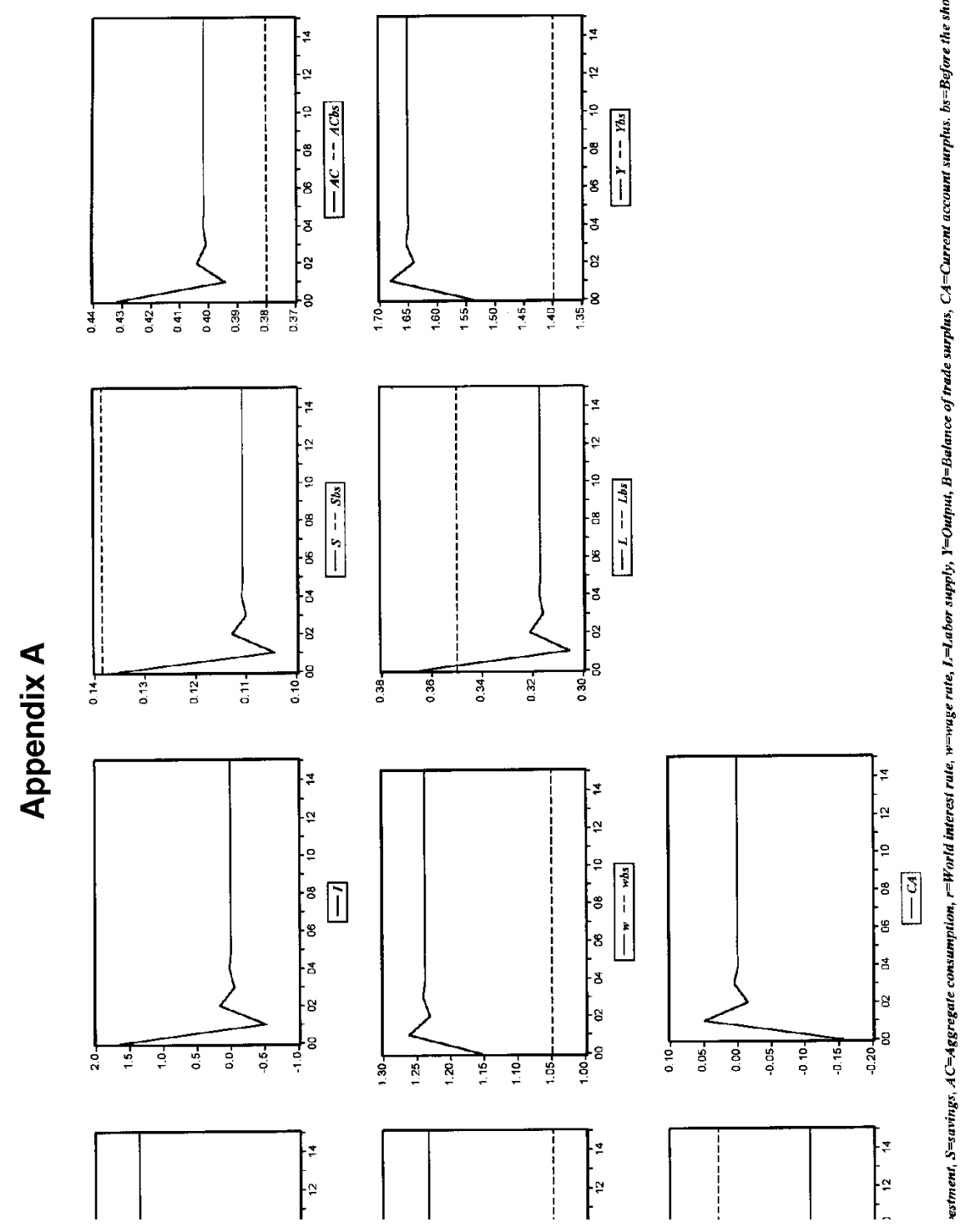

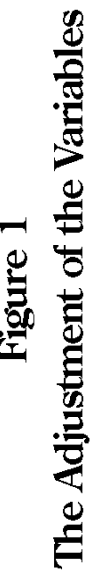




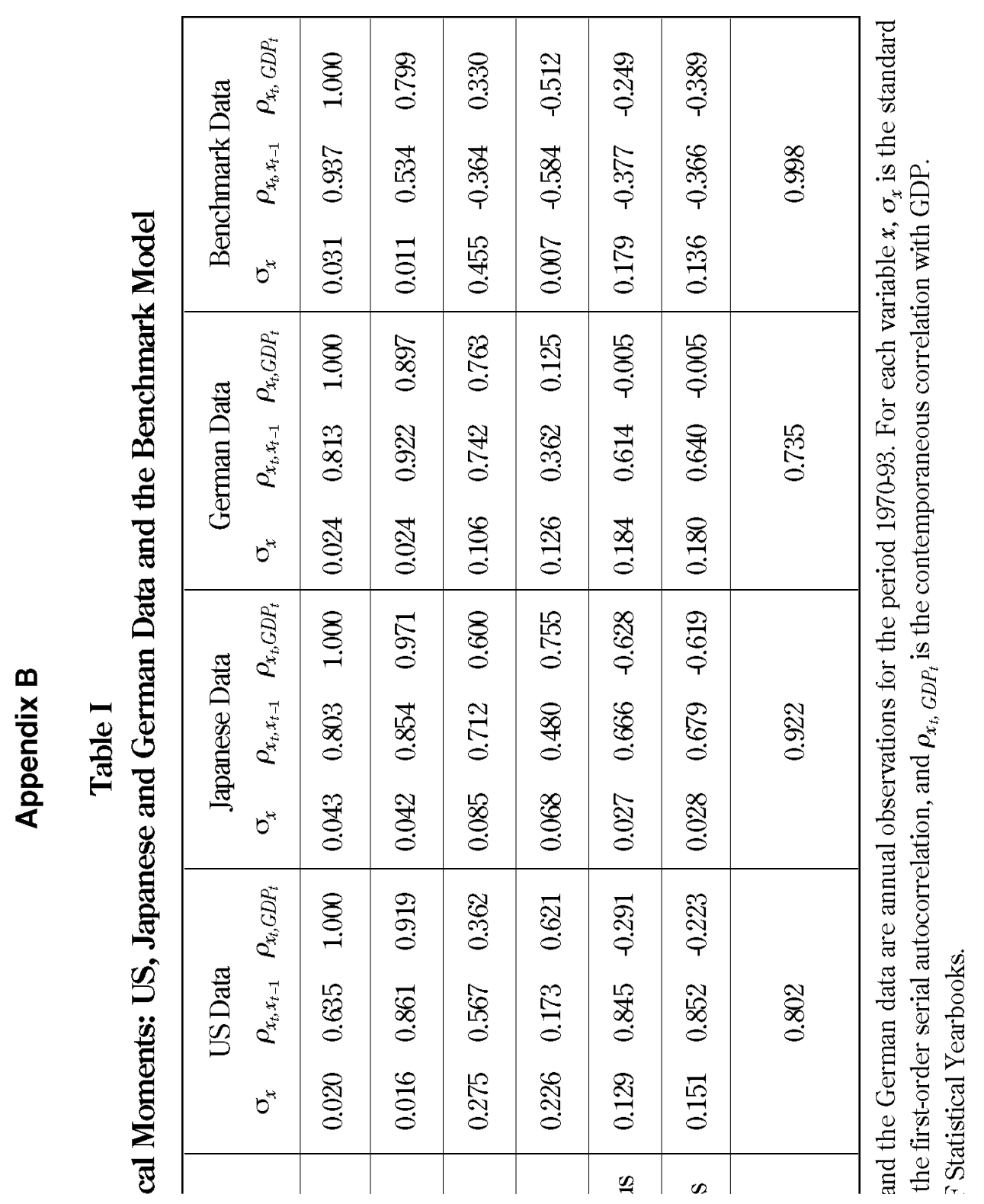




\section{Appendix C}

Equation (16) of the text reproduced here reads

$$
\begin{aligned}
& f\left(k_{t}\right)-k_{t} f^{\prime}\left(k_{t}\right)\left[f\left(k_{t}\right)-k_{t} f^{\prime}\left(k_{t}\right), f^{\prime}\left(k_{t+1}\right) ; \rho+f^{\prime}\left(k_{t}\right)-k_{t} f^{\prime}\left(k_{t}\right), f^{\prime}\left(k_{t+1}\right) ; \rho\right] \\
& -\left\{c^{1}\left[f\left(k_{t}\right)-k_{t} f^{\prime}\left(k_{t}\right), f^{\prime}\left(k_{t+1}\right) ; \rho\right]+c^{1}\left[f\left(k_{t}\right)-k_{t} f^{\prime}\left(k_{t}\right), f^{\prime}\left(k_{t+1}\right) ; \rho\right]\right\} \\
& =k_{t+1}\left[f\left(k_{t+1}\right)-k_{t+1} f^{\prime}\left(k_{t+1}\right), f^{\prime}\left(k_{t+2}\right) ; \rho+f\left(k_{t+1}\right)-k_{t+1} f^{\prime}\left(k_{t+1}\right), f^{\prime}\left(k_{t+2}\right) ; \rho\right]
\end{aligned}
$$

By linearizing this equation, we get

$$
\begin{aligned}
& \left(\partial w_{t} / \partial k_{t}\right) L_{t}\left(k_{t}-k \downarrow+w_{t}\left(\partial L_{t} / \partial w_{t}\right)\left(\partial w_{t} / k_{t}\right)\left(k_{t}-k\right)+w_{t}\left(\partial L_{t} / \partial r_{t+1}\right)\left(k_{t+1}-k \downarrow\right.\right. \\
& +\left(\partial w_{t} / \partial k_{t}\right) L_{t}\left(k_{t}-k \downarrow+w_{t}\left(\partial L_{t} / \partial w_{t}\right)\left(k_{t}-k\right)+w_{t}\left(\partial L_{t} / \partial r_{t+1}\right)\left(k_{t+1}-k\right)-\right. \\
& \left(\partial c_{t}^{1} / \partial w_{t}\right)\left(k_{t}-k \downarrow-\left(\partial c_{t}^{1} / \partial r_{t+1}\right)\left(k_{t+1}-k \downarrow-\left(\partial c_{t}^{1} / \partial w_{t}\right)\left(\partial w_{t} / \partial k_{t}\right)\left(k_{t}-k \downarrow-\right.\right.\right. \\
& \left(\partial c_{t}^{1} / \partial r_{t+1}\right)\left(\partial w_{t} / \partial k_{t}\right)\left(k_{t+1}-k\right)-\left(L_{t}+L_{t}\right)\left(k_{t+1}-k\right)-k\left(\partial L_{t} / \partial w_{t}\right)\left(\partial w_{t} / \partial k_{t}\right) \\
& \left(\mathrm{k}_{\mathrm{t}+1}-\mathrm{k} \downarrow-\mathrm{k}\left(\partial \mathrm{L}_{\mathrm{t}} / \partial \mathrm{r}_{\mathrm{t}+1}\right)\left(\partial \mathrm{r}_{\mathrm{t}+1} / \partial \mathrm{k}_{\mathrm{t}+1}\right)\left(\mathrm{k}_{\mathrm{t}+2}-\mathrm{k} \downarrow-\mathrm{k}\left(\partial \mathrm{L}_{\mathrm{t}} / \partial \mathrm{w}_{\mathrm{t}}\right)\left(\partial \mathrm{w}_{\mathrm{t}} / \partial \mathrm{k}_{\mathrm{t}}\right)\left(\mathrm{k}_{\mathrm{t}+1}\right.\right.\right. \\
& -k \downarrow-k\left(\partial L_{t} /\left(\partial r_{t+1}\right)\left(\partial r_{t+1} / \partial k_{t+1}\right)\left(k_{t+2}-k\right)\right.
\end{aligned}
$$

Solution to this equation yields:

$$
a_{1}\left(k_{t}-k\right)+a_{2}\left(k_{t+1}-k\right)+a_{3}\left(k_{t+2}-k\right)+a_{4}=0
$$

By using standard methods, we find the eigenvalues:

$$
\begin{aligned}
& \lambda_{1}=-1.14223, \\
& \lambda_{2}=-0.31643 .
\end{aligned}
$$

Since the absolute value of one eigenvalue $\left(\lambda_{1}\right)$ exceeds 1 , the element of the eigenvector cor responding to that eigenvalue is set equal to zero to prevent explosive paths. 